\title{
Implementation of Social Conflict Management in Local Government: A Policy Content Analysis
}

\author{
Laode Ahmad Pidana Bolombo \\ Director of Social, Economy, and Culture Resilience \\ Ministry of Home Affairs, Republic of Indonesia
}

Received: Jun. 6, 2021 Accepted: Jun. 28, 2021 Online published: Jul. 1, 2021

doi:10.5296/jpag.v11i2.18711 URL: https://doi.org/10.5296/jpag.v11i2.18711

\begin{abstract}
This study discusses the implementation of handling social conflicts in West Java Province in 2015 - 2019. This study begins with a study of the conflicts that occur, as well as evaluating the handling of social conflicts that have occurred in West Java Province in three dimensions, namely conflict prevention, conflict cessation, and post-conflict handling as a form of implementation of policies on handling social conflicts. The theoretical framework of this research is made in stages, starting from the grand theory using the theory of Government Science in the context of the government administration system to regulate, directing relations between community members, middle range theory which uses public policy theory, and applied which uses the theory of policy implementation proposed by Grindle, which sees the successful implementation of two aspects, namely 1) the content of policy aspect, which is seen from six variables, namely the interests that are affected, the type of benefit, the degree of change, the location of the policy. decision making, program implementers, resources involved. This study concludes that the implementation of social conflict handling policies in West Java Province, there are still some shortcomings or implementation that has not been maximized in terms of several indicators both in policy content and policy context.
\end{abstract}

Keywords: policy implementation; policy implementer; social conflict management

\begin{abstract}
This study discusses the implementation of handling social conflicts in West Java Province in 2015 - 2019. This study begins with a study of the conflicts that occur, as well as evaluating the handling of social conflicts that have occurred in West Java Province in three dimensions, namely conflict prevention, conflict cessation, and post-conflict handling as a form of implementation of policies on handling social conflicts. The theoretical framework of this research is made in stages, starting from the grand theory using the theory of Government Science in the context of the government administration system to regulate, directing
\end{abstract}


relations between community members, middle range theory which uses public policy theory, and applied which uses the theory of policy implementation proposed by Grindle, which sees the successful implementation of two aspects, namely 1) the content of policy aspect, which is seen from six variables, namely the interests that are affected, the type of benefit, the degree of change, the location of the policy. decision making, program implementers, resources involved. This study concludes that the implementation of social conflict handling policies in West Java Province, there are still some shortcomings or implementation that has not been maximized in terms of several indicators both in policy content and policy context.

Keywords: policy implementation, policy implementer, social conflict management

\section{Introduction}

The policy on handling social conflict is in principle a program that has been determined by the government which is implemented by the government and local governments to achieve the expected goals. For this reason, so that social conflict management policies can achieve the desired goals and objectives, they should be realized in real and meaningful activities. As stated by Hamdi (2014: 37) that "Every public policy will always contain meaning as an effort by the community to find solutions to problems they face in everyday life".

The government plays an important role in the process of formulating and making public policies, and even at the level of implementation in the form of programs, in order to regulate various problems that occur, which are their responsibility. Therefore, there is the formulation and implementation of a public policy, because of the goals to be realized and the public problems that must be overcome (Brodkin, 2011). This means that public policies are steps or directions as a form of government or local government intervention to overcome various problems that occur in people's lives.

The success of public policy implementation is influenced by two fundamental variables, namely the content of the policy and the implementation environment (context of implementation). Variables in the content of this policy include: 1) Interest Affected, the extent to which the interests of the target group or target groups are contained in the content of the policy; 2) Type of Benefits, the type of benefits received by the target groups; 3) Extent of Change Envision, the extent to which changes are desired from a policy; 4) Site of Decision Making, whether the location of a program is correct; 5) Implementer Program, whether a policy has mentioned the implementor in detail; and 6) Resources Committed, whether a program is supported by adequate resources, while the policy environment variables include: 1) Power, Interest, and Strategy of Actor Involved, how much power, interest, and strategy are owned by the actors involved in policy implementation; 2) Institution and Regime Characteristics, Characteristics of institutions and regimes in power; 3 ) Compliance and Responsiveness, the level of compliance and responsiveness of the target group (Grindle, 1980).

In the implementation of government policies, there are usually a number of actors in various positions (Hill \& Peter, 2002). The difference between policy implementers and policy objects (the target population) is important. Policy implementers (or simply implementers) 
are actors who are one way or another charged with the use of facilities. The implementing organization includes all the implementers and the division of their respective tasks.

Social conflict is a feud and/or physical clash with violence between two or more community groups that lasts for a certain time and has a wide impact which results in insecurity and social disintegration so as to disrupt national stability and hinder national development Therefore, it is necessary to make various efforts to handle social conflicts in a patterned, directed and integrated and sustainable manner so that the root problems that cause conflicts can also be completely overcome.

West Java Province is the province with the largest population in Indonesia, due to its proximity to the capital city. This condition also causes the population in West Java to be very multicultural. The diversity of tribes and religions is very visible in West Java Province. This condition resulted in many social conflicts in West Java Province. The number of social conflicts that occurred in West Java Province reported to the Directorate General of Politics and General Administration of the Ministry of Home Affairs from 2015 - 2018 can be seen clearly in the following graph:

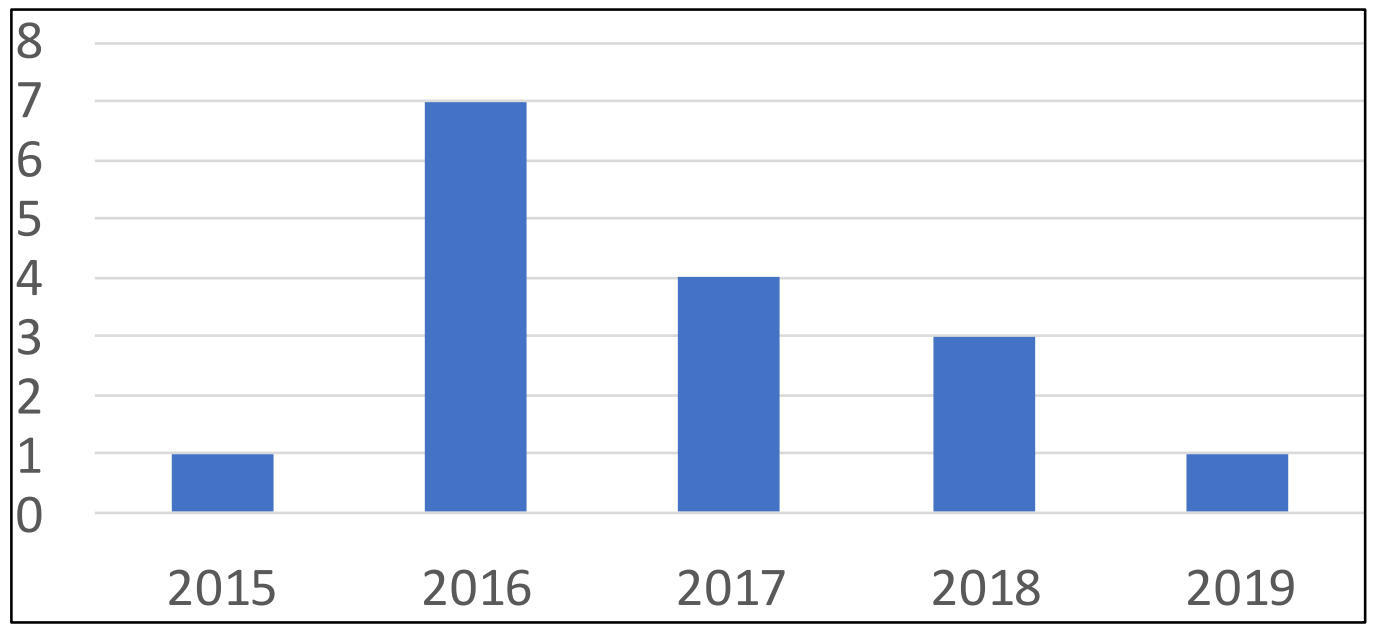

Graph 1. Number of Social Conflicts in West Java Province in 2015-2018

Source: Center for Communication and Information of the Directorate General of Politics and Public Administration, Ministry of Home Affairs

As an area that is geographically close to the State Capital of Jakarta, West Java Province also influences and is greatly influenced by the dynamics, situation and condition of the State Capital. Whenever there is a national change, West Java plays an important role, and vice versa, besides the socio-political dynamics in West Java, it will also have a significant impact on the national situation and conditions. There are several prominent problems that often occur in the West Java region, including: terrorism, flow problems such as; Fajar Nusantara Movement (GAFATAR) and the Indonesian Ahmadiyah Congregation (JAI), the potential for Sunni-Shia conflict, the revival of leftist groups, radicalism, separatism, conflicts related to the construction of houses of worship, land disputes, trade union movements, pressure group 
movements and crime transnational (Mayhew, 2005).

According to Law Number 7 of 2012 concerning Handling Social Conflicts, social conflict events can be grouped into several types, namely conflicts related to SARA, land/plantation disputes, construction of houses of worship, forest areas, expansion of new autonomous regions, and mining. Based on the pre-research conducted by the researcher, the events that can trigger social conflict also occur quite a lot in West Java Province, which can be seen in more detail in the following graph:

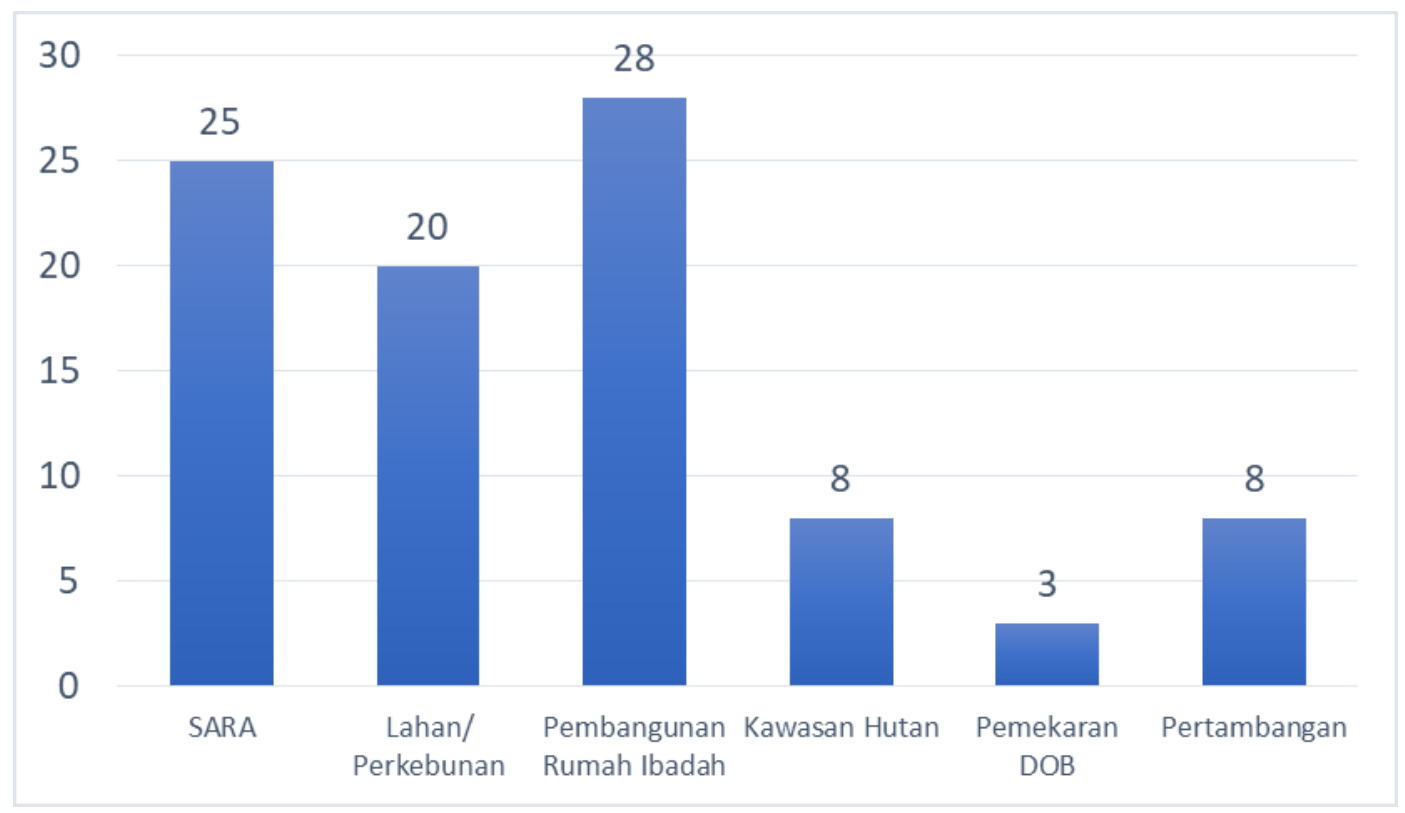

Graph 2. Number of Potential Events for Social Conflict in West Java Province in 2015-2019

Source: National Unity and Political Agency of West Java Province

Conflict handling is a series of activities carried out in a systematic and planned manner in situations and events both before, during, and after a conflict occurs which includes conflict prevention, conflict cessation, and post-conflict recovery. Conflict prevention is a series of activities carried out to prevent conflicts from occurring by increasing institutional capacity and early warning systems. Conflict cessation is a series of activities to end violence, save victims, limit the expansion and escalation of conflict, and prevent the increase in the number of victims and loss of property (Mayhew, 2005). Post-Conflict Recovery is a series of activities to restore the situation and improve the harmonious relations in the community due to conflict through reconciliation, rehabilitation, and reconstruction activities.

To overcome the handling of social conflicts in West Java Province, an Integrated Team for Handling Social Conflicts in West Java Province has been formed. This Integrated Team is chaired by the Governor of West Java Province, with the deputy chairman of the Regional Secretary, and each leader from the existing vertical agencies/institutions in West Java Province, namely the Regional Police of West Java Province, Regional Military Command, High Prosecutor's Office, and the National Police Agency. Regional Intelligence. Meanwhile, as a secretary in the Kesbangpol Agency as an agency that has duties and functions related to 
political dynamics, national unity, and the implementation of general government.

The Integrated Team for Handling Social Conflicts in West Java Province is expected to develop an action plan for dealing with social conflicts in West Java Province, both in terms of the stages of conflict prevention, conflict cessation, and post-conflict handling. The number of action plans for each dimension of the social conflict stages that have been prepared by the Province of West Java can be seen more clearly in the following graph 3:

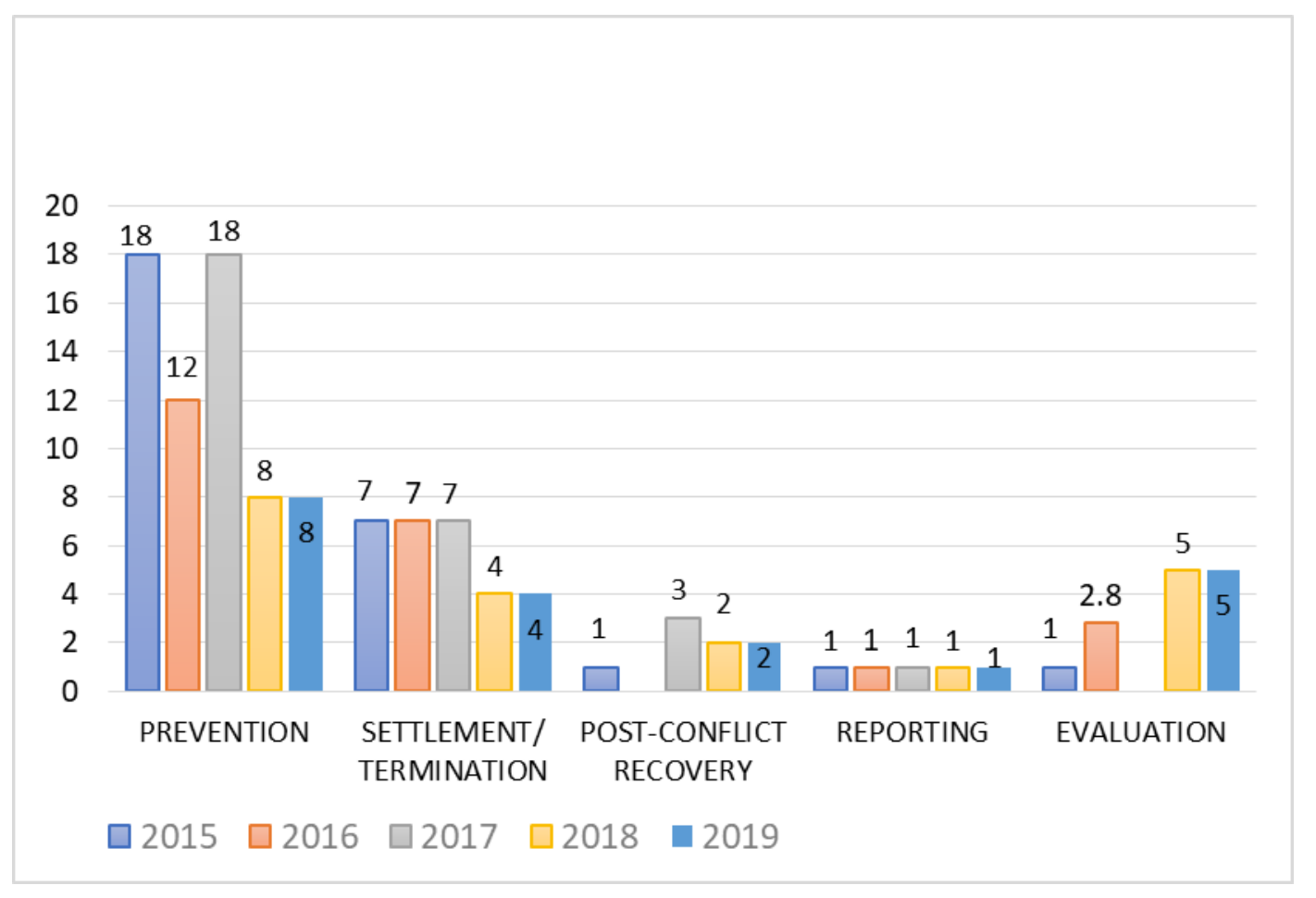

Graph 3. Action Plan for Handling Social Conflict West Java Province 2015-2019

Source: National Unity and Political Agency of West Java Province.

The Directorate General of Politics and General Administration of the Ministry of Home Affairs evaluates the action plans for handling social conflicts that are prepared and implemented by each Regional Government. From the results of the evaluation carried out, the action plans for social conflict handling activities that have been carried out in West Java Province have not shown maximum results, and still get an average achievement score of $50 \%$ on a scale of $0 \%-100 \%$. There are several reasons why this research takes a case study in West Java Province. First, the community has not experienced real benefits from the action plans that have been implemented by the West Java Provincial Government regarding the handling of social conflicts, as can be seen from the recurrence of events that could potentially lead to social conflict, where conflict events are triggered by almost the same problems every year. every year, and the potential for social conflict also remains high every year despite prevention efforts in the form of socialization to the community. The failure to implement policies for handling social conflicts indicates the blockage of information channels, resulting in misunderstandings between policy implementers and the public about programs because the policy information channels are vague and not transparent (Bakke, 
2006). Unclear information will also have an impact on inconsistent social conflict handling policies, in other words, explanations sometimes conflict with the reality and needs of the target group, when a policy is implemented.

Second, in carrying out the handling of social conflicts in West Java Province, it has not been supported by adequate quality resources both in terms of human resources, budgeting and facilities and infrastructure. The determination of the budget related to the handling of social conflicts in West Java Province is also considered to be still less than optimal considering that the handling of social conflicts is one of the strategic programs mandated in the Guidelines for the preparation of the APBD issued by the Ministry of Home Affairs.

Third, the determination of the division of tasks and authority between members of the integrated team for handling social conflicts has also not gone well. In an organizational structure, it is very necessary to have a clear division of tasks and flow arrangements through standard operating procedures (SOPs) (Edward III, 1980). However, the absence of SOPs that serve as guidelines in the implementation of social conflict handling policies in West Java Province causes the activities to be held to be hampered due to inefficient bureaucratic structures. This condition also resulted in the action plans that have been prepared every year have not been accommodated by all agencies/institutions that are included in the membership of the Integrated Team for Handling Social Conflicts in West Java Province. Furthermore, from the results of the assessment carried out by the Ministry of Home Affairs, the assessment and ranking obtained by the Province of West Java has not received maximum results. In fact, there are several assessments of the action plan that received a score below $60 \%$ (Range $0-100 \%$ ).

Fourth, there is no good cooperation and joint commitment by the institutions or agencies involved in the Social Conflict Integrated Handling Team to maximally carry out their respective duties and functions together to be able to resolve social conflict problems and prevent social conflicts from reoccurring. Fifth, reports on the handling of social conflicts in West Java Province which have not been fully consolidated between the institutions/agencies involved, giving the impression that the governance of social conflict handling is merely a formality of prerequisites for institutional responsibilities according to their duties and functions in handling social conflicts. There are still differences in perceptions and interests in the internal institutions or agencies involved in the Social Conflict Integrated Handling Team, where they assume that the more data on handling social conflicts, the less optimal performance. Handling social conflicts has not been perceived as a responsibility and a necessity to be able to maintain the integrity of the Unitary State of the Republic of Indonesia.

From the description above, it is clear that there is a gap between expectations and reality in terms of handling social conflicts, especially in West Java Province. Responding to this phenomenon, the government and local governments should find a solution through the policies adopted. In the pattern of government relations between the governed and the governed, a policy taken by the government for its effectiveness really requires integration and coordination among the various components involved. The integration in question is 
between policy makers, policy implementers and the community as the policy target group, in order to realize the achievement of the expected goals.

\section{Method}

This study uses a qualitative approach with the reason that the Implementation of Social Conflict Handling in West Java Province is not only related to proportional knowledge, but also involves tacit knowledge, which is almost impossible to obtain through a rationality approach (Denzin \& Strauss, 2006; Farr, 2008). Through a naturalistic approach, the researcher hopes to be able to construct the emics of the informants and take a complete and complete picture of the phenomena in the field. There are two types of data used in this study, namely primary data and secondary data. Primary data in the form of information and facts sourced from informants to various questions asked. This primary data includes various questions related to the Implementation of Social Conflict Management in West Java Province. Determination of informants in this research is to use focus and sample techniques in accordance with the main idea of the study. The technique used to determine informants is Criterion based selection and also snow-ball. This technique was deliberately chosen by the researchers because the research process required an initial analysis of the informants to be selected based on certain criteria according to the type of data needed. While the snow-ball technique is a technique for determining key informants to add and clarify the statements expressed by previous informants.

\section{Result and Discussion}

\section{Implementation of Social Conflict Management Policies in West Java Province Provinsi}

Policies that have been formulated certainly have certain goals or targets to be achieved, where the targets will only be achieved when implemented. This means that the policies that have been formulated and made are not just to be used as plans, but are implemented to be able to provide changes with the available resources according to the objectives that have been set. Policy implementation is an effort to achieve certain goals with certain means and in a certain time sequence (Castro, 2001). In order for the implementation of the policy to be carried out according to the goals and objectives to be achieved, the role of supporting elements such as resources and organization is needed. However, the implementation of a policy does not always run smoothly because there are many factors that can affect the level of success in its implementation in the field.

From the view above, it can be observed that the implementation of the policy is basically not in a vacuum, so that there are various factors that surround it and affect the implementation of the policy. The difficulties that are often encountered in the implementation of a policy made by the government are due to the lack of attention from the government bureaucracy to see the various aspects surrounding the implemented policies. Even though the support for valid and credible initial data and information as input and study material in policies is not paid attention to, causing a policy taken by the government to be less than optimal when implemented to the community as a target group. Likewise, the implementation of the Social Conflict Handling policy in West Java Province, where the West Java Province Kesbangpol 
Agency is the leading sector as stated in the formulation of this research problem.

a. Interest Affected

The interests of the affected group are defined as the interests of the groups who are affected or who are the target group with the introduction of public policies, in this case Law Number 7 of 2012 concerning Handling of Social Conflicts and Government Regulation No. 2 of 2015 concerning Handling of Social Conflicts. As stated by Grindle that policy implementation will involve many interests of the target group that is the policy target (Grindle, 1980). The extent to which the interests of the target group are affected is the rationale for researchers to study more deeply.

With the roll out of the policy product, it gives an indication that basically the Government shows a commitment to show commitment in overcoming various problems related to social conflict. This is supported by the statement of one research informant through the results of interviews as follows:

The background of the issuance of Law no. 7 of 2012 concerning the Handling of Social Conflicts, namely because the transition to democracy in an increasingly open world order has resulted in accelerated social dynamics, including foreign intervention factors. This condition places Indonesia as one of the countries prone to conflict, especially horizontal conflicts. The conflict has proven to have resulted in a loss of security, the emergence of community fear, environmental damage, property loss, loss of life and psychological trauma such as revenge, hatred, and antipathy, thus hampering the realization of general welfare. The conflict management system that has been developed so far is more militaristic and repressive in nature. In addition, laws and regulations related to Conflict Handling are still partial and in the form of laws and regulations issued by the Government such as in the form of Presidential Instructions, Presidential Decrees and Presidential Regulations (Results of Interview with Director General of Politics and General Administration, August 2020).

Based on the results of these interviews, it can be concluded that the diversity of ethnicity, religion, race, and culture of Indonesia with a population of more than 230 million people, on the one hand is a national wealth that can directly or indirectly contribute positively to efforts to create community welfare. But on the other hand, these conditions can have a negative impact on national life if there are development inequalities, social and economic inequality and inequality, as well as uncontrolled dynamics of political life. The rise of social conflicts in Indonesia, which is partly due to the lack of internalization of democratic ethics into social ethics in the lives of Indonesian people, especially freedom that is not balanced with awareness to respect the rights of others and the weak legal awareness of the community to comply with applicable legal and social institutions.

The presence of Law no. 7 of 2012 concerning the Handling of Social Conflict, is a very important momentum for the Government's concern in eradicating all forms and problems related to social conflict in every region in Indonesia. The Law on Handling Social Conflicts determines the objectives of conflict resolution, namely to create a safe, peaceful, peaceful 
and prosperous society; maintain peaceful and harmonious conditions in social relations; increase tolerance and tolerance in the life of society and the state; maintain the continuity of government functions; protect life, property, and public facilities and infrastructure; provide protection and fulfillment of victims' rights; and restore the physical and mental condition of the community. he extent to which they can comply with and adapt to the content of the policies implemented, depends on the suitability of the contents of the policy (program) with the expectations of those who are the target/target of the policy (Grindle, 1980).

From the community's perspective, Law Number 7 of 2012 concerning the Handling of Social Conflicts determines the objectives of conflict resolution, namely to create a safe, peaceful, peaceful and prosperous community life; maintain peaceful and harmonious conditions in social relations; increase tolerance and tolerance in the life of society and the state; maintain the continuity of government functions; protect life, property, and public facilities and infrastructure; provide protection and fulfillment of victims' rights; and restore the physical and mental condition of the community. Perpetrators are a group of people who fight or experience physical conflicts that last for a certain time and have a wide impact that result in insecurity and social disintegration so as to disrupt national stability and hinder national development

Meanwhile, from the perspective of policy makers, the conflict management system that has been developed so far is more militaristic and repressive in nature. In addition, laws and regulations related to Conflict Management are still partial and are in the form of laws and regulations issued by the Government such as in the form of Presidential Instructions, Presidential Decrees and Presidential Regulations. In this condition, the Government, in this case the President of the Republic of Indonesia, ordered the Minister of Home Affairs to discuss and formulate a law related to the handling of social conflicts together with the House of Representatives of the Republic of Indonesia (DPR RI). Furthermore, it was clarified again by drafting the Implementing Regulations for the Social Conflict Handling Act as contained in the Government Regulation of the Republic of Indonesia Number 2 of 2015. It is hoped that this regulation can assist Regional Governments in handling social conflicts in a more comprehensive and directed manner.

\section{b. Type of Benefit}

Understanding the benefits is something that is felt by the target group (target group) with the implementation of the policy. According to Grindle (1980), if the policy provides direct benefits for many parties or groups, then it is more likely to get a positive response and reduce the risk of conflict, but if the benefits are felt indirectly, then there is a great tendency for the policy to receive less response from the target group so that become a trigger for conflict, the end result of which is that the policy does not reap success in achieving the final goal. This is in accordance with the idea put forward by Sudarwan quoting Edwards III, stating that policy is a step in solving fundamental social problems (Edward III, 1980). Based on the thoughts put forward by Grindle, the meaning of benefits can be compiled into two categories, namely direct benefits, meaning direct benefits that can be received and felt by the target group by enacting the policy, while indirect benefits are indirect benefits (Edward III, 
1980). received and felt by the beneficiaries in this case the target group (Target Group).

Thus, when a search is conducted on the results of interviews with informants, an explanation is obtained through several interviews as follows:

Parties who benefit from the enactment of Law Number 7 of 2012 concerning Handling of Social Conflicts and Government Regulation of the Republic of Indonesia Number 2 of 2015 concerning Implementing Regulations of Law Number 7 of 2012 concerning Handling of Social Conflicts are all provincial communities, especially community groups who are vulnerable to feuds or physical clashes with violence between two or more community groups that result in insecurity and social disintegration, who are legally entitled to protection and protection from the government from social conflict problems that psychologically and materially will harm their lives and their future. With the existence of this regulation related to the handling of social conflicts, the main thing that can be done to prevent social conflict from happening is by maintaining peaceful conditions in society, developing a system for peaceful dispute resolution, reducing potential conflicts, and building an early warning system. The next benefit of this regulation is expected to be able to stop conflicts that have occurred so as to minimize more victims and losses. Finally, this regulation is expected to serve as a guide in post-conflict recovery so that the same thing doesn't happen in the future as well as post-conflict rehabilitation and reconstruction. In addition, with this regulation, both the government and relevant stakeholders in these efforts can be supported through government funding in this case the West Java Provincial Budget in carrying out these efforts through various programs and activities in accordance with their duties and authorities (Results of Interviews with Head of the West Java Province Kesbangpol Agency, July 2020).

Based on the statements of various research informants, it can be concluded that the beneficiaries and benefits obtained by the existence of Law Number 7 of 2012 concerning Handling of Social Conflicts and Government Regulation of the Republic of Indonesia Number 2 of 2015 concerning Implementing Regulations of Law Number 7 of 2012 concerning the Handling of Social Conflicts, are 1) for the DPR RI, the People's Representative Council of the Republic of Indonesia. With the roll out of the policy, it means that the legislature has obtained several benefits, including first, the appointment of initiatives and attention to issues related to handling social conflicts. This attention has been realized in 2 (two) forms, namely in the form of approving, deciding, and establishing policies as stipulated in Law Number 7 of 2012 concerning Handling of Social Conflicts and Government Regulation of the Republic of Indonesia Number 2 of 2015 concerning Regulations Implementing Laws. Number 7 of 2012 concerning Handling Social Conflict. Second, is the point of success that has been carried out by members of legislation (DPR RI) in discussing, approving, deciding, and enacting the Laws and Government Regulations showing that members of the legislation (DPR RI) have performed their duties and functions well by focusing on preparation of regulations that protect the public; 2) For the government, the West Java Provincial Government will have material resources both sourced from the Regional Revenue and Expenditure Budget (APBD), Deconcentration Funds (APBN), as well 
as other sources that are not binding in implementing and succeeding programs related to handling social conflict. Local governments also have a forum to coordinate together in solving all problems related to social conflicts; 3) For the community, will get a safe, peaceful, peaceful, and prosperous life; maintain peaceful and harmonious conditions in social relations; increase tolerance and tolerance in the life of society and the state; maintain the continuity of government functions; protect life, property, and public facilities and infrastructure; provide protection and fulfillment of victims' rights; and restore the physical and mental condition of the community.

\section{c. Extend of Change Envisioned}

According to Theodore Lowi in Grindle, revealing that the policy being made will have a broad impact on the type of political activity stimulated by the policy-making process (Grindle, 1980). This observation can be applied with the same validity to the implementation process which encourages consideration of the implementation of various programs. For example, the extent to which public action seeks to introduce changes in social, political, and economic relations. Law Number 7 of 2012 concerning Handling of Social Conflicts regulates the Handling of Social Conflict which is carried out through three stages, namely Conflict Prevention, Conflict Cessation, and Post-conflict Recovery.

\section{d. Site of Decision Making}

The decision-making process in a policy plays an important role. In order for decision making to be important in its implementation, this section must explain where the decision making of a policy to be implemented is located. According to Wahab quoting Anderson that "Decision making means choosing the best alternative and a number of available alternatives" (Anderson, 2010). While Syamsi quoting Landy argues that "A decision is a conclusion that is used after consideration, which occurs after one possibility is chosen while putting the others aside" (Landy, 1993).

Based on the Organizational Structure of the West Java Province Integrated Team for Social Conflict Handling, it can be explained that the Governor of West Java Province as the location for decision making and as the Chair of the Integrated Social Conflict Handling Team, has the following duties:

a. Responsible for all activities of the Integrated Team for Social Conflict Management;

b. Provide guidance to members of the Integrated Team for Social Conflict Management;

c. Submit recommendations/suggestions/inputs and reports to the Minister of Home Affairs, through the Secretary of the Integrated Team for Social Conflict Handling.

In this case, the chairman is assisted by 5 (five) deputy chairmen who are the Head of the Indonesian Police, TNI, High Prosecutor's Office and the Intelligence Agency located in West Java Province, who have the following duties: 
a. Assist the chairman in directing, leading, coordinating and controlling the implementation of the Integrated Team for Social Conflict Management;

b. Assist the chairman in formulating and submitting reports

c. Together with the secretary, prepare and submit a report on the implementation of the Action Plan for the Integrated Social Conflict Management Team.

This is in accordance with what was stated by the informant, through the results of the interview as follows:

The location of Decision Making on Social Conflict Handling Policies in West Java Province, in this case is the Governor/Head of Region as Chair, based on the mandate of the Regulation of the Minister of Home Affairs of the Republic of Indonesia Number 42 of 2015 concerning the Implementation of Coordination of Social Conflict Handling assisted by 5 (five) representatives chairman who represents every Indonesian Police Institution, TNI, High Prosecutor and Intelligence Agency located in West Java Province. Meanwhile, for the technical field, it is mostly carried out by the Secretary, deputy secretary and members. (Results of Interview with Head of West Java Province Kesbangpol Agency, July 2020).

Based on the description of the Governor's duties as the Chair of the Integrated Team for Social Conflict Handling and the results of interviews with research informants, it will be difficult for the Governor to make decisions regarding the handling of social conflicts, both at the stages of conflict prevention, conflict cessation, and conflict recovery because too many agencies and institutions are included in the in the Integrated Team for Social Conflict Management. The main task of the Governor of West Java Province as the head of the Integrated Team for Handling Social Conflict in West Java Province is to be responsible for all activities of the Integrated Team for Handling Social Conflict. This means that the Governor must be able to provide direction and especially provide decisions so that every agency/institution that is part of the Integrated Team for Handling Social Conflict in West Java Province can arrange programs or activities related to handling social conflicts, especially in the dimensions of the stages of conflict prevention, as well as in conflict resolution. and post-conflict recovery.

\section{e. Program Implementers}

The implementation of a policy really requires the support of competent and capable implementing officials for the success of the implemented policy. This understanding is meant that, before the policy is implemented, it should be implemented as early as possible so that it is known who will implement the policy, and which organizations are involved and the data on the target groups receiving the policy. However, one thing that is very determinant in policy implementation is the readiness of implementers who have the ability to implement the policy, both technical skills, managerial skills and the ability or knowledge to plan, coordinate, control and integrate every decision.

A policy certainly has no meaning, if the policy is not implemented. For this reason, it is 
necessary to have support from program implementers who are actors directly involved in policy implementation. The actors involved in handling social conflicts in this study relate to the Provincial Government which carries out the function of direct service to the wider community. In other words, implementing policies that include agencies or institutions that are members of the Integrated Team for Handling Social Conflicts, government structures, norms, and patterns of relationships that occur between institutions, social institutions, and customary institutions, all of which contribute to the influence to the implementation of social conflict management policies.

The implementation of a policy or program is certainly supported by the existence of competent and capable policy implementers for the success of a policy. According to Grindle that "Decision made during policy formulation may also indicate who is to be charged with executing various programs, and such decisions can affect how the policy pursued" (Grindle, 1980). Therefore, the success of the policies that have been made cannot be assessed without an implementer or implementer, because the role of the implementor is very important, without them the implementation of the policy is not carried out. Implementor is not just one but there are several, so it must be complete because each has different roles and functions that complement each other.

In a situation like this, the executor will tend to follow the instructions given by their respective superiors or follow the instructions from the superior who has the strongest influence on the existence of the executor (assessment of achievements, positions, ranks, finances) in the long term (Anderson, 2010). Thus, every policy that is implemented must be properly exposed or recorded who the program implementers are in detail, such as in handling social conflicts.

Based on the view above, the implementers or actors involved in the action, especially at the stages of guidance and counseling carried out play a very important role in efforts to achieve the goals outlined in the policy. According to Dunn, that "implementation is an application that is intended to operate the program" (Dunn, 1994).

In this case, the program/policy for handling social conflicts, in which to operate these activities, it is necessary to have quality implementing apparatus resources, so that they can achieve the expected results. However, there are several weaknesses in the implementation process, which of course have implications for the delay in the success of the program in accordance with the objectives set. Because the program implementers do not have sufficient discretion to support the success of the program due to a lack of knowledge and understanding of the content of the policy. In addition, the lack of coordination that has been built since the beginning of program planning and the delivery of inaccurate information will certainly affect the implementation of the program.

Whereas the policy program created and implemented by the government according to Arif is, "a series of actions proposed by the government in a certain environment where there are obstacles and opportunities for the proposed policy to use and overcome in order to achieve a goal. certain" (Arif \& Primastuti, 2019). The program is part of the activities which, according to Frederich, are also related to the completion of several aims and objectives. 
Although the intent and purpose of the program is not always easy to see, it is ideal that the program can show what is actually being done rather than what is proposed in some activities on a problem.

In order to make it easier for us to understand in more detail about the implementors of social conflict handling policies in West Java Province, the researchers will compile according to the institutions that are members of the Integrated Team for Social Conflict Handling and have drawn up action plans related to handling social conflicts in West Java Province so that it can be explained more specifically the fields that have the authority or competence to carry out the main tasks and functions of handling social conflicts in 3 (three) stages, namely conflict prevention, conflict resolution, and post-conflict handling in West Java Province. The program implementations in social conflict handling policies are 1) Regional Secretariat; 2) Regional Police; 3) Kodam III/ Siliwangi; 4) Regional High Prosecutor's Office of West Java Province; 5) Kesbangpol Board of West Java Province.

\section{f. Resources Committed}

Grindle (1980) defines commitment to resources as the extent to which political elite groups have a sense of concern for the provision and fulfillment of resources needed in the implementation of policy programs in the third world. The basic conditions for the execution of any public policy, in general, can only begin when general goals and objectives have been defined, a program of action has been designed, and resources, especially funds, have been allocated to achieve these objectives.

In terms of the implementation process it is a fact that decisions made at the design or formulation stage, will have a considerable impact on the results of its implementation later. This is clear considering for example the impact on the subsequent implementation of the decision to allocate three million dollars to achieve a policy goal, rather than three hundred million dollars. Thus, the availability of resources is a very basic and essential element in the implementation of public policy. This will support the implementers to solve various problems and meet the various needs imposed on them.

In managing a program to be successful, there are differences in the capacities of various bureaucratic institutions. This may be because some institutions have more active, skilled, and dedicated staff than others, some have greater support from political elites and have greater access to resources, and some are able to cope. the demands they face. In addition, the form of stated policy objectives can have an important impact on implementation. Whether the objectives are clearly or unambiguously stated and whether political and government officials agree on what objectives to display will determine the implementation of policy programs.

In this regard, according to Grindle's understanding, policy execution must be supported by the availability of adequate resource allocation so that the policy implementation process can achieve the expected goals (Grindle, 1980). Therefore, these resources relate to the following matters: 
1) Human resources, which means the quantity and quality of human resources as the main actors in the process of implementing public policies.

2) Availability of assets that must be owned by public organizations, as a basic component to produce various goods and services. For example, finance, and various facilities and infrastructure needed in the implementation of public policies.

The implementation of every public policy, such as handling social conflicts by the implementers or policy implementers, not only requires a level of ability but also requires willingness in its implementation. Understanding the attitudes and behavior of implementing officials is the most important thing in implementing policies. The attitude of the implementer (disposition) is more interpreted as a form of tendency to understand, accept, or reject that can affect the performance and ability of the implementer to implement the policy.

A policy in its implementation will run effectively, when the implementers are not only able to know and understand what they have to do, but also the form of contribution they want is fulfilled from the policy. Therefore, the disposition factor or behavior of the implementers as a whole reflects the tendency of a strong will from the implementers in carrying out each activity based on the level of obedience to all provisions as a quality standard for a policy to be implemented. This is because the policy activities for handling social conflict have general objectives and measures for their implementation. The implementation of the handling of social conflicts will certainly have a positive influence on the formation of attitudes and behavior of the community who work together and maintain a safe and peaceful situation as well as the attitudes and behavior of local government and security officials in charge of dealing with social conflicts. Therefore, in order to support and realize the implementation of policies to be more efficient and effective, the compliance and obedience of each implementing apparatus is very important.

Resources in policy implementation are one of the important factors, because without the resources to implement the program, the policy will only be formulated on paper and will only become a plan and never be realized. According to Grindle that "Differences in the degree of behavior change the program envisions for its intended beneficiaries is another way the content of policy affects its implementation" (Grindle, 1980). Meanwhile, according to Arif that "One of the factors that causes the non-achievement of policy objectives is the limited resources, both manpower, material, time and so on" (Arif \& Maksum, 2017).

Another view was put forward by Edwards III, that "the sources that support effective policies include: staff (number of personnel who have knowledge and ability), authority (authority), information (information), and facilities (facilities)" (Edward III, 1980). Staff or personnel are the most essential resources in implementing policies, because in implementing policies many are caused by the ability of personnel who are less reliable. Even a small number of personnel does not guarantee the success of a policy implementation, if it is not accompanied by skills and expertise. But on the other hand, the shortage of staff will also cause complicated problems in policy implementation. Thus, the resources (implementors) of the policy must be supported by various resources such as reliable implementing officials and the support of adequate facilities and infrastructure so that the implementation of activities 
can run well.

\section{Closing}

The changes to be achieved from the implementation of social conflict handling policies in West Java Province have not been maximized, seen from several factors in the dimensions of the stages of conflict prevention. The changes to be achieved in the dimensions of this stage are to prevent potential conflicts from turning into social conflicts marked by physical violence, and a reduction in events that have the potential to conflict, as well as the availability of data related to conflict maps and information related to conflict, which can be done through maintaining peaceful conditions in the country. the community through outreach activities on religious harmony; socialization about the equality of the position of the community with the aim that the community can respect the differences in ethnicity, language and customs of others, respect the opinions and freedoms of others, recognize and treat humans according to their dignity and worth, and recognize the equality, rights and obligations of every human being without distinction of ethnicity, descent, religion, belief, gender, social position, and skin color; develop a peaceful settlement of disputes, by always prioritizing deliberation and consensus in every decision-making as well as in settlement; reduce potential conflicts; and build an early warning system.

\section{Reference}

Anderson, J. E. (2010). Public Policy Making. Cengage Learning.

Arif, A., \& Maksum, I. R. (2017). Functional Decentralization Construct in Decentralization Policy in Indone- sia ( A study of Irrigation, Education, and Free Trade Sectors ). 21(May), 59-81.

Arif, A., \& Primastuti, A. (2019). COASTAL COMMUNITY EMPOWERMENT: METHODS, CHALLENGES AND SOLUTIONS. International Journal of Kybernology. https://doi.org/10.33701/ijok.v3i1.582

Bakke, K. (2006). Diversity, disparity, and civil conflict in federal states. World Politics, 59(1), 1-50. https://doi.org/10.1353/wp.2007.0013

Brodkin, E. Z. (2011). Policy work: Street-level organizations under new managerialism. Journal of Public Administration Research and Theory, 21(SUPPL. 2), 253-277. https://doi.org/10.1093/jopart/muq093

Castro, A. (2001). Indigenous people and co-management: Implications for conflict management. Environmental Science and Policy, 4(4), 229-239. https://doi.org/10.1016/S1462-9011(01)00022-3

Denzin, N. K., \& Strauss, A. L. (2006). Qualitative Analysis for Social Scientists. In Contemporary Sociology (Vol. 17, Issue 3). https://doi.org/10.2307/2069712

Dunn, W. N. (1994). Public Policy Analysis: An Introduction (2nd ed.). Prentice Hall.

Edward III, G. C. (1980). Implementing Public Policy. Congressional Quarlerly Press. 


\section{Macrothink}

Journal of Public Administration and Governance ISSN 2161-7104

Farr, B. C. (2008). Designing Qualitative Research. In Transformation: An International Journal of Holistic Mission Studies. https://doi.org/10.1177/026537880802500310

Grindle, M. S. (1980). Politics and Policy implementation in The Third World. Princeton University Press.

Hill, M., \& Peter, H. (2002). Implementing Public Policy. SAGE Publication.

Landy, M. (1993). Public policy and citizenship, in H. Ingram \& S. Rathgeb Smith BT Public Policy and Democracy. Brookings.

Mayhew, S. H. (2005). Hegemony, politics and ideology: The role of legislation in NGO-government relations in Asia. Journal of Development Studies, 41(5), 727-758. https://doi.org/10.1080/00220380500145263

\section{Copyright Disclaimer}

Copyright for this article is retained by the author(s), with first publication rights granted to the journal.

This is an open-access article distributed under the terms and conditions of the Creative Commons Attribution license (http://creativecommons.org/licenses/by/4.0/). 